\title{
Walter E. Berdon, MD — passing of a legend
}

\author{
Peter J. Strouse ${ }^{1}$
}

Received: 11 September 2017 / Accepted: 12 September 2017 / Published online: 23 September 2017

(C) Springer-Verlag GmbH Germany 2017

In this issue, we note the passing of Walter E. Berdon, MD. Special thanks go to Tom Slovis, Terry Levin and Aparna Joshi for a poignant look back on Walter's life and contributions.

For 20 years, Walter was the North American editor of Pediatric Radiology. As a current editor, I find it unfathomable to think of running a journal without computers, without Internet and without modern communications (email, cell phones). Walter was a terrific editor, taking great interest in the science and personal interest in the people, and always seeking to push the envelope of pediatric radiology. His insightful and witty commentaries provided perspective and stimulated further thought on important papers in the journal.

In many ways, Walter was one of the last giants of pediatric radiology. He was a link to our founding fathers. Walter helped to guide our specialty through its troublesome toddler and adolescent years - as journal editor, as a society leader (president of the Society for Pediatric Radiology [SPR]) and as a mentor. He was a constant presence at the SPR meetings into his early $80 \mathrm{~s}$. He trained and mentored innumerable pediatric radiologists at Columbia, through his journal work, as a society leader and through his wonderful passion for pediatric radiology. Well after the age that most of us retire, Walter maintained an innate enthusiasm and quest to learn more about pediatric radiology. Frequently, he

Peter J. Strouse

Rad-Ped-Radiol-Journal@med.umich.edu

Section of Pediatric Radiology, C. S. Mott Children's Hospital, Room 3-231, Department of Radiology,

University of Michigan Health System,

1540 E. Hospital Drive, Ann Arbor, MI 48109-4252, USA would develop a relationship with a bright young pediatric radiologist about a common area of interest and mentor that person.

I am very fortunate to have been introduced to Walter Berdon by Tom Slovis. I had the good fortune early in my career to experience Walter's enthusiasm while working on a paper with Walter on horseshoe adrenal glands with cases drawn from five institutions. When I was a new journal editor, Walter served as my "grand-mentor," passing on a few pearls of wisdom and instilling a sense of passion and importance for the work of a journal editor.

Walter's emails always distinctively came in ALL CAPS. I never did figure out why, but I always assumed it was a way to express his enthusiasm and the importance of the subject at hand, intended or not. Regardless, I always knew from the sender's email - or the "WEB" at the end - that the content was important, and I greatly valued every communication that he sent.

Walter's passing leaves a void in pediatric radiology, yet many of us are who we are in part because of Walter. The daily work that we do in pediatric radiology today is based on the contributions of Walter and those whom he fostered as a journal editor, society leader, mentor and great friend. Thank you, Walter!

If I have seen further than others, it is by standing upon the shoulders of giants.

-Isaac Newton

Conflicts of interest None 